\title{
Music: A Tool in Transforming the Social Status of Special Needs Children
}

\author{
Tepika Rodsakan \\ Srinakharinwirot University, Thailand \\ tepika_joy@hotmail.com
}

\begin{abstract}
There are some attempts to politically encourage the rights of social status to Special Needs Children by both Thai government and non-government organizations. Practically, the fact indicates that the Special Needs Children's social status and roles are vaguely partial in terms of whether opportunities or social rights. The researcher has experimented by organizing traditional Thai musical activities to Special Needs Children, the case study of Panyawutikorn School. Pre-test and post-test results and observation evidently have shown that the musical skills are increasingly improved. Similarly, an empirical data presents they took pride proudly when they are being praised in their developing skills by teachers, parents as well as H.R.H. Mahachakri Sirindhron princess, has been at Panyawutikorn school in order to attend Thai musical performance of Special Needs Children, the attention of princess can encourage them to be more engaged in musical performance of Special Needs Children and also people involved. As mentioned above, 'music' is utilized as a tool to transforms the social status and give them a chance of playing role as givers. The traditional Thai music ensemble of Special Needs Children is requested to broadly show their abilities in many places such as hospitals, elderly cares, and in other school activities. Truly, music therefore is effectively able to transmit the social status of the Special Needs Children from previously they were defined as always receivers to be currently understood as givers. Furthermore, the study also provided the number of children is stepping up and paying more attentions in musical activities. This is to really consider the attempts to push up Special Needs Children in the same level of citizenship hierarchy.
\end{abstract}

Keywords: music abilities, special needs children, social status

\section{INTRODUCTION}

As a word 'citizenship', leads us to consider about a status of being citizen; people are factors of society which prosperously propel the countries for development. All the people thus deserve to be treated impartially in terms of human rights and security as basic elements in welfare service of equality. On the other hand, in fact of reality, there are some groups of people with special needs exist in societies according to National statistical office of Thailand has revealed that almost two million (3\%) of Thai population are Special Needs Children including the Physically Handicapped (PH), the Deaf and Hard of Hearing (DE), the Blind and Visually Handicapped (VH), the Learning Disabled (LD), and the Mentally Retarded (MR). Previously, they lacked of opportunities to be served 
the privilege as ordinary people, however, there had been some attempts to politically encourage the rights of social status to Special Needs Children for a long-standing. In 2007, Thai government has approved an Empowerment of Persons With Disabilities Act for Special Needs Children, synopses of an Act is to consider promotion and support of activities of State and private agencies related to the Empowerment of Persons with Disabilities. They have the right to access and utilize public facilities such as education, vocational rehabilitation, as well as acceptance and participation in social, economic and political activities etc. Nonetheless, in the reality, role and status of Special Needs Children are unobvious neither social opportunities nor the right.

Art is beneficial to encourage Special Needs Children's development. From previous studies and researches pointed the results out that art enables to elevate the sicial development effectively. The purpose of Art for Special Needs Children tends to expectedly focus on developing behaviour and being in readiness in real life. In addition, Art is a process of decreasing a social gap by group activities mixing ordinary children with Special Needs Children.

Music is known as art of sound which contributes the benefit in encouraging development for Special Needs Children in many ways. For applying music as a tool to improve Special Needs Children's behaviour in terms of health, emotion, social, and intelligence by musical activities, which are comprised and organized by numerous disciplines. The music activities are designed in order to apply diverse functions for Special Needs Children e.g. rhythmic movement, singing, music creativity, musical practicum. Moreover, the musical activities also help Special Needs Children to commonly blend together with whether Special Needs Children or ordinary children and to strengthen relationship with teacher and parents. Musical activities still help to cut down a gap between music and Special Needs Children. Likewise, music is not only limited to serve to normal people but music also worthily enact in many ways. To expand music for serving in diversity of dimensions, music can be spotlighted to particularly involve assisting development of human behaviour and to widen the function of music as tangible knowledge. A readiness of mutually coexisting and interacting with other people for Special Needs Children, music is defined as neutral tool to be utilized for teaching Special Needs Children, and be able to aid them achieving the goal. Teachers are just contributing person who organize learning environments, but absolutely an activity is supposed to be propelled by children.

The musical activity for Special Needs Children is a real expression to the intellectual knowledge of music to society and emphasis in equality. The musical activities are a learning process that to advocate and stimulate the Special Needs Children's ability. Furthermore, contribution of social act can cause and accomplish the understanding of people as well as change social attitude of realization and opening mind in acceptance. 


\section{MUSIC FOR SPECIAL NEEDS CHILDREN}

The teaching development by using musical instrument is wildly affirmed of encouraging Special Needs Children learning development as a science of development and fulfilment of ability in terms of health, emotion, social, intelligence as well as way of life and important skills to survive in reality. As a result of research, An integrated musical instrument for the mentally disable children, the tool was specifically designed by considering about correspond with connecting to Special Needs Children, considered about figures, sizes, colours, and playing of instrument. To refer to Thai music by basically introducing four skills of Thai music including picking, bowing, rapping, blowing and adding two more skills are shaking and pressing, all of six skills are gathered in order to contain in an integrated musical instrument. An instrument was made for testing with maximum 18 children.

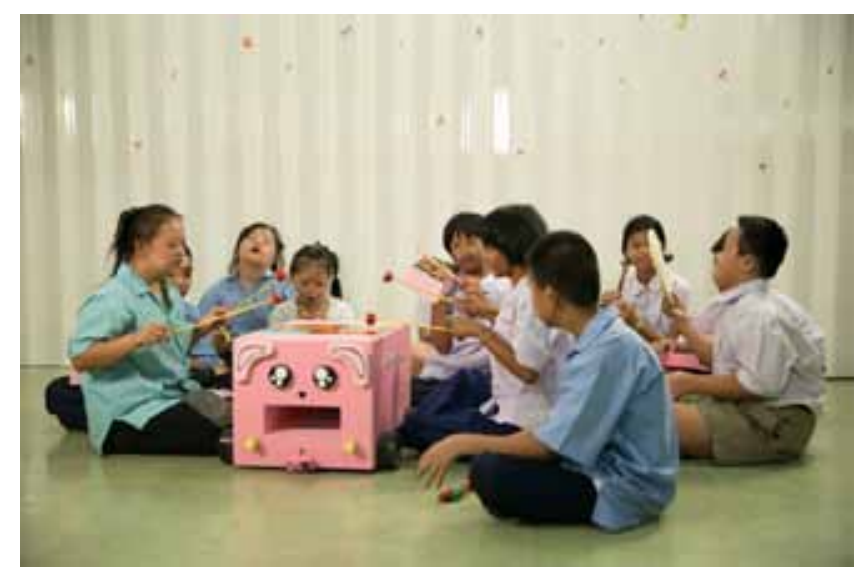

Figure 1: An Integrated Musical Instrument for the Mentally Disabled Children. Tepika Rodsakan

In experimental research, the sample used in the research was 8 educable mentally disabled children from Panyawutikorn School aged between 8-10 years old. The sample had been tested and confirmed by the psychologist to have IQ from 50-70, the sample were not sound sensitive and neither multiple handicaps. The test were used emphasize on behaviour observation and interview. Result of the research presents general responding of the Mentally Retarded (MR) children are fine and additionally, their musical skill were being developed during testing. The behaviour observation has found that Special Needs Children were interested and joyful in musical activity and from interview shows Special Needs Children are satisfied playing solely and also playing together.

Musical skill development test is an assistance to stimulate a skill of music and Special Needs Children enabled to improve higher skill. So that, Special Needs Children who have sufficient skill could gather together in Panyawutikorn ensemble. The ensemble has presented Thai music in public places. Getting compliments from parents and teachers are willpower of Special Needs Children. The impressive situation is H.R.H. Princess Maha Chakri Sirindhron, visited at Panyawutikorn school in order to attend Thai musical performance of Special 
Needs Children, the attention of the princess highly encourage them to be more engaged in musical performance of Special Needs Children.

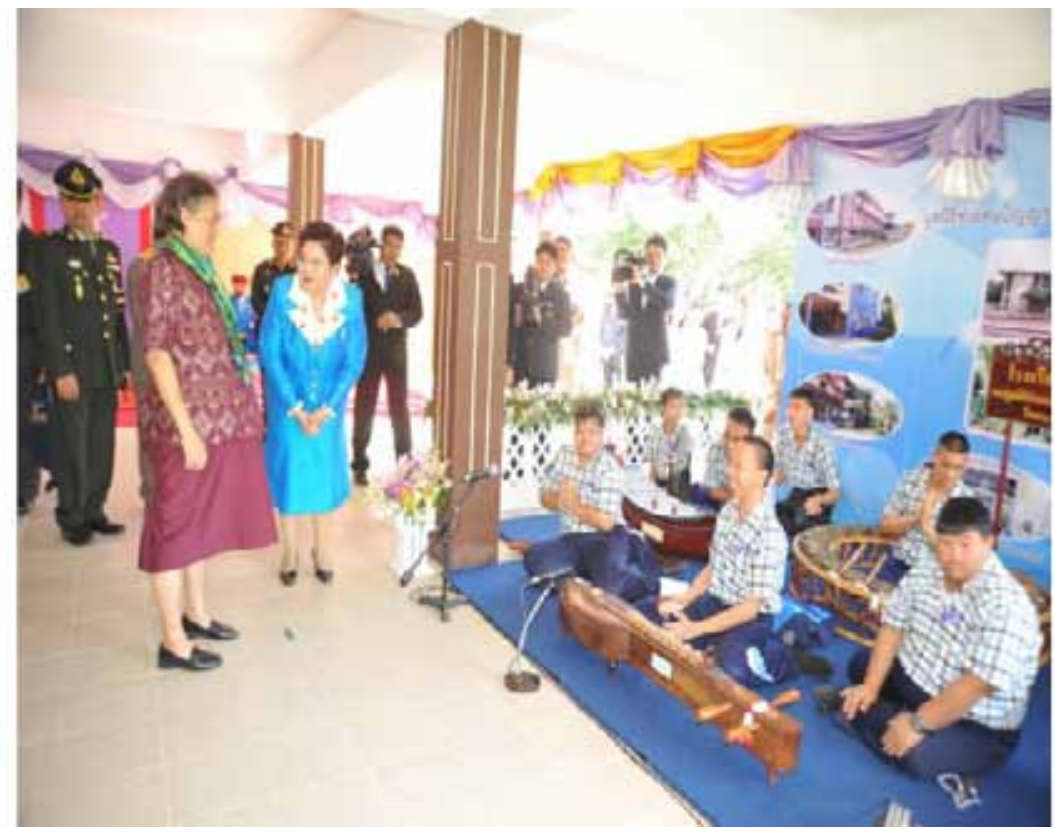

Figure 2: H.R.H. Princess Maha Chakri Sirindhron watching Panyawutikorn Thai music ensemble. Tepika Rodsakan

\section{MUSIC: A TOOL IN TRANSFORMING THE SOCIAL STATUS OF SPECIAL NEEDS CHILDREN}

While there are some attempts to politically encourage the rights of social status to Special Needs Children, but practically Special Needs Children are still different from normal children. They are always identified as receivers and usually need social association. A matter of fact, they have thought not to be understood as always receivers nor treated as if they were burdens of society. Their self-esteem pushes them up and they steadfastly desire to be citizen of country as normal. Their skills are able to contribute something to national progression in terms of education, economy, politic, social, and culture similarly as major population. Social capital improvement of Special Needs Children is needed because the social capital is a factor to raise them to be visible appearance. An appearance as social status is lucid for them to act as possible as normality. For instant, a case of Panyawutikorn Special Needs Children are encouraged in musical skill to continuously perform in ensemble by full team Special Needs Children members. Because of continuity, it can establish cultural capital according to Pierre Bourdieu (1997) said, 'cultural capital' means that the value individuals receive from the social engineering process. This value has become a property that allows people to increase their value.

As indication of music ability is a cultural capital, to change music into a tool for transforming and to enhance and support social status and opportunity of Special Needs Children. The activity also encourages them to alter the role as receivers into givers. To refer to 'Voluntary concert at Ramathibodi hospital', 
Special Needs Children would be lulling traditional Thai music for patients on every first Tuesday in first week monthly at the hospital at first round is $9.00-10.30$ a.m. and second round is 10.30 a.m. - 12.45 p.m. and other weeks performing by military Thai music ensemble or The Provincial Electricity Authority Thai music ensemble. The traditional Thai music ensemble of Special Needs Children is requested to broadly show their abilities in many places such as elderly cares, and in other school activities. Because of outside activities, Special Needs Children can feel they are not lonely and activities support them to be confident in the role of givers. They tend to be more enthusiastic in participating musical activities and subsequently inherit to the other next generation. As the director of Panyawutikorn school Ms.Oranuch Chaiphat mentioned, "the feedback from performing music at Ramathibodi hospital is all appreciated in musical ability of Special Needs Children, many of the audients expected the musicians were ordinary children and moreover, every times playing are the happiness of Special Needs Children through they feel eager and expressing their smiling". The happiness is a power to support them to continue a role of citizen and responsibility.

\section{CONCLUSION}

Musical cultural capital is progression which fully encourages Special Needs Children about music skill shows their potential development and. Music and Special Needs Children role currently is constructed to help each other. Music becomes a tool in transforming the social status of Special Needs Children. Previously they were identified as receivers and so far they can play role in the giver status as similar as members of society.

\section{REFERENCES}

Bourdieu, Pierre. The Forms of Capital. In Richardson, J. Handbook of Theory and Research for the Sociology of Education. Westport, CT: Greenwood. 1986, 46-58.

Chaiphat, Oranuch. Personal Interview. September 11, 2012.

Tepika Rodsakan. The Creation of an Integrated Musical Instrument for the Mentally Disabled Children. D.F.A. (Music). Bangkok: Faculty of Fine and Applied Arts, Chulalongkorn University. (2013), 97-98. 